\title{
Nagssugtoqidian tectonics at the western end of the Itivdleq shear zone, West Greenland
}

\section{David Nash}

From field work, centred around the settlement of Itivdleq, a picture of the Nagssugtoqidian deformation in this area is presented (fig. 1).

Major structure-forming movements occurred under high-grade metamorphic conditions (amphibolite-facies) and are divided into two stages. During the second stage a swarm of basic dykes, the Kangâmiut dykes, were emplaced.

\section{Stage 1}

The first stage (pre-dyke, fig. 2) is characterised by large scale, ductile shearing (shear plane vertical, striking $092^{\circ}$ ) which selectively reworked pre-existing granulite-facies gneisses and formed a broad band, c. $10 \mathrm{~km}$, of east-west trending shear zones which collectively are referred to as the Itivdleq shear zone. The zone can be traced eastwards for at least 50 $\mathrm{km}$ and in the Itivdleq area has a dextral movement sense and a shallow ( $30^{\circ}$ on the regional

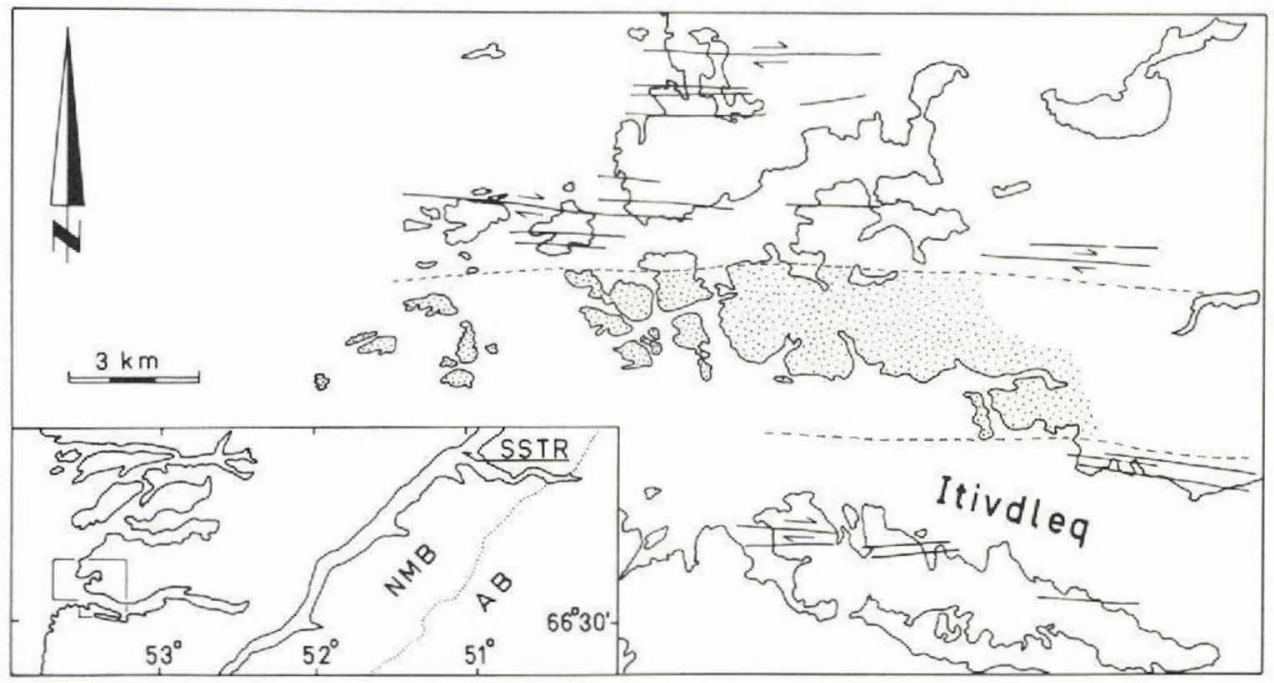

Fig. 1. Sketch map of the western part of Itivdleq fjord showing major shears in the E-W trending Itivdleq shear zone. The central zone of pervasive, E-W shear fabrics is dotted. Framed area in insert map shows area covered by this figure and figures $2 \& 3$. 


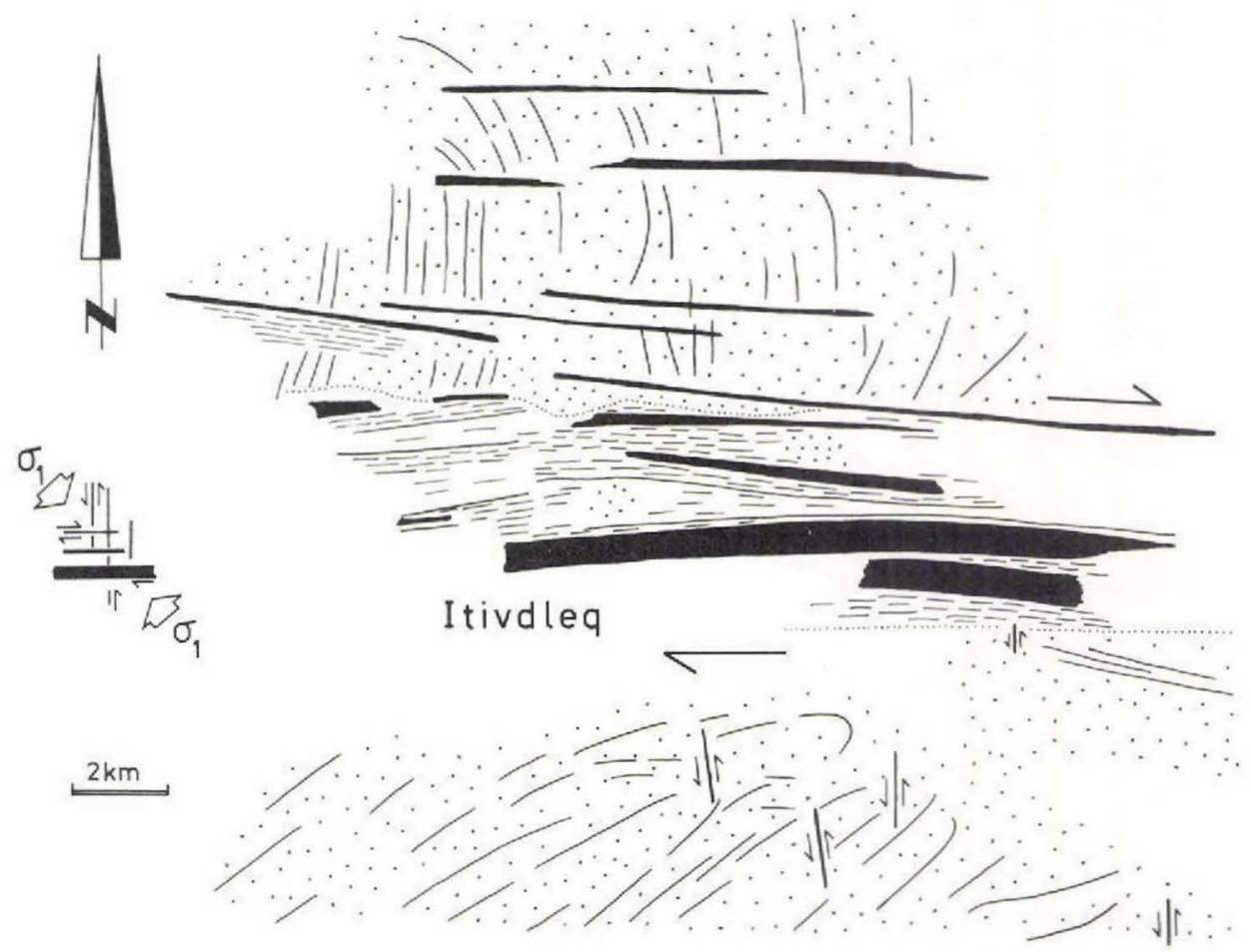

Fig. 2. Schematic representation of stage 1 shears in Itivdleç. Undeformed granulite facies areas shown dotted with trend lines. Shear zones are thick, black lines and strong fabric is indicated by fine strike lines. Some minor, N-S, ductile shear zones probably represent the complementary shear set to the E-W shears.

shear plane), westward plunging movement direction. The zone forms part of a large belt of ductile shearing ( $40 \mathrm{~km}$ wide) striking ENE and referred to as the Ikertôq shear belt (Baket al., 1975).

\section{Stage 2}

The second stage (pre-, syn-, and post-dyke, fig. 3) of deformation resulted from a change in the orientation of the maximum principal stress from NW-SE to N-S. As a consequence of this shift in orientation east-west shearing ceased and new structures were generated which variably reworked the earlier shear zone fabrics. The response of the basement, as reflected in the style of the resultant structures, is related areally to the distribution of east-west shear fabrics. In areas of relatively rigid granulite-facies, a conjugate set of minor (pre-, and post-dyke), ductile shear zones (NE-SW and NW-SE) were formed. Dykes in these areas remain largely undeformed except for minor intra-dyke shear zones. Within the Itivdleq shear zone, the conjugate shear set is absent though the dykes are more extensively 


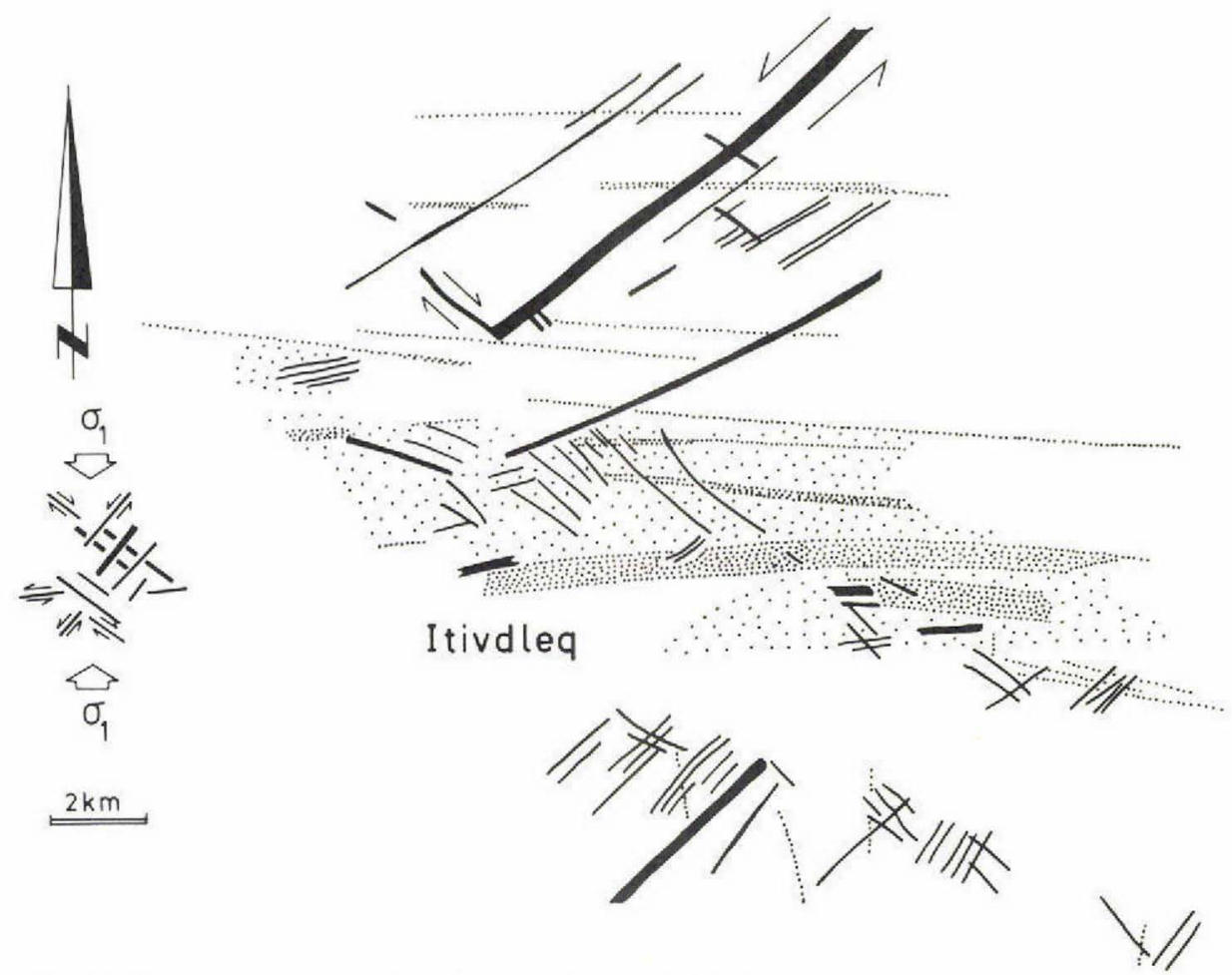

Fig. 3. Schematic representation of stage 2 shears in Itivdleq. Stage 1 shears are shown dotted.

deformed. The main modification to the east-west shear fabrics involves a weak superimposed flattening deformation combined locally with almost coplanar, ESE-WSW, ductile shearing with a sinistral sense of movement.

\section{Discussion}

This two-stage structural interpretation of the Itivdleq shear zone may be applicable, on a much larger scale, to the Ikertôq shear belt. The same arguments regarding the cessation of east-west shearing apply equally well. Furthermore, the attitude of the Nag. 2 thrust plane along the northern boundary of the shear belt implies an orientation of $\sigma_{1}$ at a high angle to the pre-existing shear plane. Could the regional Nag. 2 orientation of $\sigma_{1}$ have existed even prior to the emplacement of the basic dykes? What is more, are the Stage 2 structures (ductile, conjugate shear sets orientated NE-SW and NW-SE) an early or contemporaneous product of the same stress system which later also produced the large scale overthrusting throughout the shear belt?

A further point of interest concerns the overlap between the orientations of the Stage $2 \sigma_{1}$ and the undeflected NNE trend of the main Kangâmiut dyke swarm. Since the emplacement 
of the Kangâmiut dykes still remains an unsolved problem it is worth inquiring whether there may be some relationship between the regional orientation of the dykes and the Stage 2 stress field.

\section{References}

Bak, J., Sørensen, K., Grocott, J., Korstgård, J. A., Nash, D. \& Watterson, J. 1975: Tectonic implications of Precambrian shear belts in western Greenland. Nature 254, 566-569.

King Homes,

1-8-10, Kami-Meguro,

Meguro-Ku,

Tokyo 153,

Japan 